\title{
Glycosaminoglycan mimetic peptide nanofibers promote mineralization by osteogenic cells
}

\author{
Samet Kocabey, Hakan Ceylan, Ayse B. Tekinay*, Mustafa O. Guler* \\ Institute of Materials Science and Nanotechnology, National Nanotechnology Research Center (UNAM), Bilkent University, 06800 Ankara, Turkey
}

\section{A R T I C L E I N F O}

Article history:

Received 31 March 2013

Received in revised form 18 June 2013

Accepted 8 July 2013

Available online 18 July 2013

\section{Keywords:}

Glycosaminoglycan

Self-assembly

Peptides

Mineralization

Cell-material interactions

\begin{abstract}
A B S T R A C T
Bone tissue regeneration is accomplished by concerted regulation of protein-based extracellular matrix components, glycosaminoglycans (GAGs) and inductive growth factors. GAGs constitute a significant portion of the extracellular matrix and have a significant impact on regulating cellular behavior, either directly or through encapsulation and presentation of growth factors to the cells. In this study we utilized a supramolecular peptide nanofiber system that can emulate both the nanofibrous architecture of collagenous extracellular matrix and the major chemical composition found on GAGs. GAGs and collagen mimetic peptide nanofibers were designed and synthesized with sulfonate and carboxylate groups on the peptide scaffold. The GAG mimetic peptide nanofibers interact with bone morphogenetic protein-2 (BMP-2), which is a critical growth factor for osteogenic activity. The GAG mimicking ability of the peptide nanofibers and their interaction with BMP-2 promoted osteogenic activity and mineralization by osteoblastic cells. Alkaline phosphatase activity, Alizarin red staining and energy dispersive X-ray analysis spectroscopy indicated the efficacy of the peptide nanofibers in inducing mineralization. The multifunctional and bioactive microenvironment presented here provides osteoblastic cells with osteogenic stimuli similar to those observed in native bone tissue.
\end{abstract}

(c) 2013 Acta Materialia Inc. Published by Elsevier Ltd. All rights reserved.

\section{Introduction}

Regeneration of damaged bone tissue is a significant health problem in aging populations. Fractures, degenerative diseases and infections cause bone loss. Inducing bone formation and regeneration using allografts, natural extracellular matrix (ECM) components or collagen-derived materials may cause immunological responses or disease transmission. For this reason synthetic scaffold materials have been developed to induce tissue regeneration [1]. Peptide amphiphile molecules can be decorated with various bioactive sequences in high density while self-assembling into nanofibrillar networks similar to natural ECM [2]. These characteristics of peptide amphiphile molecules provide considerable opportunity to design ECM mimetic structures, which can be utilized to direct cellular behavior and guide proper restoration of damaged tissues by creating functional microenvironments [3-5].

The ECM plays an indispensible role in bone regeneration and mineralization. It regulates cell-specific interactions via collagenous and non-collagenous molecules, which guide cellular behaviors such as adhesion, migration, proliferation and differentiation

\footnotetext{
* Corresponding authors. Tel.: +90 312290 3572/3552; fax: +90 3122664365 (M.O. Guler and A.B. Tekinay).

E-mail addresses: atekinay@unam.bilkent.edu.tr (A.B. Tekinay), moguler@ unam.bilkent.edu.tr (M.O. Guler).
}

[6-8]. In bone tissue the ECM is composed of approximately $50-70 \%$ inorganic calcium and phosphate minerals and $20-40 \%$ organic components, which mainly consist of collagen type I surrounded by proteoglycans, glycosaminoglycans (GAGs) and other proteins [9]. GAGs have important roles in bone remodeling, such as stabilizing growth factors and enhancing growth factor-receptor interactions [10]. Bone ECM contains a variety of sulfated and non-sulfated GAGs, including chondroitin sulfate, dermatan sulfate and hyaluronan, while heparin and heparan sulfate can be found in bone marrow [11-13]. These GAGs can trigger bone remodeling by affecting cellular proliferation and differentiation via binding growth factors and through direct cell surface receptor activation [14]. While sulfated GAGs, including heparin and heparan sulfate, induce binding of growth factors and facilitate growth factor-mediatedsignaling, several non-sulfated GAGs, such as hyaluronan, are able to interact with cell surface molecules such as CD44, CD168, intercellular adhesion molecule (ICAM) and hyaluronan-mediated motility receptor (RHAMM) to initiate cellular responses such as differentiation and migration [15-18]. In previous studies over-sulfated chondroitin was shown to promote collagen deposition, alkaline phosphatase (ALP) activity and mineral accumulation in osteoblasts [19]. Moreover, synthetic materials composed of sulfated hyaluronan increased tissue non-specific ALP activity and formation of osteoblastic cell aggregates [20]. 
In addition to the interaction between GAGs and cells, the types of growth factors interacting with GAGs are also crucial determinants for bone regeneration. A large number of bone regulating proteins and cytokines, such as bone morphogenetic proteins, tumor necrosis factor (TNF)- $\alpha$, osteoprotegerin, receptor activator of nuclear factor $\kappa B$ ligand (RANKL) and other members of transforming growth factor- $\beta$ family were previously shown to interact with GAGs [21-24]. Among them, BMP-2 is one of the most osteoinductive growth factors, inducing osteogenic differentiation of multipotent mesenchymal stem cells and directing bone formation [25-28]. BMP-2 binding GAGs found in the ECM synergistically enhance the osteogenic activity of cells. When used with highly sulfated heparin the osteogenic activity increases approximately 5-fold compared with BMP-2 alone [29]. Besides increasing the biological activity of BMP-2, GAGs also serve as delivery agents by capturing and increasing the local concentration of proteins [30]. Therefore, utilizing a GAG mimetic system with osteoinductive properties is a promising technique for bone regeneration applications. We have previously shown that GAG mimetic peptide nanofibers can interact with several growth factors, including vascular endothelial growth factor (VEGF), fibroblast growth factor-2 (FGF-2) and hepatocyte growth factor (HGF) [31], and can induce differentiation of cells involved in angiogenesis and neural differentiation [32-33]. In this study we show that GAG mimetic peptide nanofibers with sulfonate and carboxylate groups can provide a suitable microenvironment for bone regeneration and mineralization. We also demonstrate that these peptide nanofibers bind to BMP-2 and increase the viability, proliferation and mineralization of osteogenic cells.

\section{Materials and methods}

\subsection{Materials}

All protected amino acids, lauric acid, [4-[ $\alpha$ - $\left(2^{\prime}, 4^{\prime}\right.$-dimethoxyphenyl) Fmoc-aminomethylphenoxyacetomidonorleucyl-MBHA resin (Rink amide MBHA resin), 2-(1H-benzotriazol-1-yl)-1,1,3,3tetramethyluroniumhexafluorophosphate (HBTU) and diisopropylethylamine (DIEA) were purchased from Nova-Biochem, $A B C R$, or Sigma-Aldrich. rhBMP-2 (PHC7141), Calcein-AM and other cell culture materials were purchased from Invitrogen. Anti-BMP-2 antibodies and reagents for ELISA assay were purchased from R\&D. All other chemicals and materials used in this study were purchased from Fisher, Merck, Alfa-Aesar and/or Sigma Aldrich.

\subsection{Synthesis and characterization of peptide amphiphile molecules}

Peptide amphiphile (PA) molecules were synthesized on Rink amide MBHA resin or Fmoc-Glu(OtBu)-Wang resin using a standard Fmoc solid phase peptide synthesis method. $0.25 \mathrm{mmol}$ resin and $0.5 \mathrm{mmol}$ amino acids were used in the synthesis. Amino acid coupling was performed with 2 equivalents of amino acids activated with 1.95 equivalents of HBTU and 3 equivalents of DIEA for $2 \mathrm{~h}$. Fmoc removal was performed with $20 \%$ piperidine-dimethylformamide (DMF) solution for $20 \mathrm{~min}$. 10\% acetic anhydrideDMF solution was used to permanently acetylate unreacted amine groups after each coupling step. DMF and dichloromethane (DCM) were used as washing solvents after each step. To synthesize sulfonated PAs a p-sulfobenzoic acid was added to the side-chain of lysine, which has 4-methytrityl (Mtt) side-chain protection as used for selective deprotection of amine groups (see Scheme S1). Mtt removal was performed by shaking the resin for $5 \mathrm{~min}$ with trifluoroacetic acid (TFA):triisopropylsilane (TIS): $\mathrm{H}_{2} \mathrm{O}: D C M$ at a ratio of $5: 2.5: 2.5: 90$. Cleavage of the PAs and protection groups from the resin was carried out with a mixture of TFA:TIS: $\mathrm{H}_{2} \mathrm{O}$ at a ratio of
95:2.5:2.5 for $3 \mathrm{~h}$. Excess TFA was removed by rotary evaporation. The PAs in the remaining solution were precipitated in ice-cold diethyl ether overnight. The precipitate was collected by centrifugation next day and dissolved in ultrapure water. This solution was frozen at $-80^{\circ} \mathrm{C}$ for $4 \mathrm{~h}$ and then lyophilized for $4-5$ days. The peptides were identified using a quadruple time of flight mass spectrometer with electrospray ionization source equipped with a reverse phase analytical high performance liquid chromatography (HPLC). The purification of PAs was performed using a preparative HPLC system (Agilent 1200). In order to remove residual TFA positively charged peptide amphiphiles were treated with $0.1 \mathrm{M} \mathrm{HCl}$ solution and lyophilized. The yield of PAs after purification was $\sim 70 \%$ for negatively charged PAs and $90 \%$ for lauryl-VVAGK-Am (K-PA). All peptide batches were freeze-dried and reconstituted in ultrapure water at $\mathrm{pH} 7.4$ before use.

\subsection{Preparation and characterization of self-assembled PA nanofibers}

PA stock solutions were prepared in distilled water and adjusted to $\mathrm{pH} 7.4$ before self-assembly. For nanofiber formation lauryl-VVAGEGD-K ( $p$-sulfobenzoyl)-S-Am ( $\mathrm{SO}_{3}-\mathrm{PA}$ ) and K-PA were mixed at a $1: 3$ ratio in order to stabilize all net charges. In the same way lauryl-VVAGE (E-PA) and K-PA were mixed at a $1: 2$ ratio. For surface coatings used in cellular experiments $1 \mathrm{mM}$ PA mixture was coated on tissue culture plate (TCP) surfaces and then placed in a fume hood to dry. To measure the thickness of the PA coatings the coated surfaces were investigated by scanning electron microscopy (SEM) after drying (3.64 $\pm 0.19 \mu \mathrm{m}$ for $\mathrm{SO}_{3}-$ $\mathrm{PA} / \mathrm{K}-\mathrm{PA}$ and $4.27 \pm 0.25 \mu \mathrm{m}$ for E-PA/K-PA) (Fig. S9). SEM and transmission electron microscopy (TEM) imaging techniques were used to visualize gel formation. For SEM imaging 1 wt.\% PA solutions were mixed at $1: 2$ and $1: 3$ ratios and then dehydrated sequentially in $20 \%, 40 \%, 60 \%, 80 \%$, and $100 \%$ ethanol. Samples were critical point dried with an Autosamdri ${ }^{\circledR}-815 \mathrm{~B}$ Tousimis and coated with $5 \mathrm{~nm} \mathrm{Au} / \mathrm{Pd}$ before imaging. A FEI Quanta 200 FEG scanning electron microscope with an electron-transfer dissociation (ETD) detector in high vacuum mode at $10 \mathrm{keV}$ beam energy was used. For TEM imaging the samples were prepared by mixing $1 \mathrm{mM}$ PA solutions at $1: 2$ and $1: 3$ ratios on a 200 mesh carbon TEM grid. After 10 min incubation the unbound peptide nanofibers were rinsed off with water and the remaining peptide nanofibers were air-dried in a fume hood. TEM imaging was performed with a FEI Tecnai G2 F30 transmission electron microscope at $300 \mathrm{kV}$. Circular dichroism (Jasco J-815) samples were prepared using $1 \times 10^{-5} \mathrm{M} \mathrm{SO}_{3}-\mathrm{PA} / 3 \times 10^{-5} \mathrm{M} \mathrm{K}-\mathrm{PA}$ and $1 \times 10^{-5} \mathrm{M} \mathrm{SO}_{3}-\mathrm{PA} /$ $2 \times 10^{-5} \mathrm{M}$ K-PA mixtures. Measurements were performed from 300 to $190 \mathrm{~nm}$ with three acquisition points. For the Fourier transform infrared spectroscopy (FTIR) analysis 1 wt.\% PA mixtures $\left(\mathrm{SO}_{3}-\mathrm{PA} / \mathrm{K}-\mathrm{PA}\right.$ and E-PA/K-PA) were prepared, lyophilized, and pellets obtained after mixing with $\mathrm{KBr}$. A Vortex70 Fourier transform infrared spectrometer was used to identify the FTIR spectrum of the peptide nanofibers in the spectrum range $4000-400 \mathrm{~cm}^{-1}$. An Anton Paar Physica RM301 rheometer was used to reveal the viscoelastic properties of the nanofiber network with a $25 \mathrm{~mm}$ plate configuration and a gap distance of $0.5 \mathrm{~mm}$ at $25^{\circ} \mathrm{C}$. $1 \mathrm{mM}$ PA concentrations at the abovementioned ratios were allowed to gel for 15 min prior to measurement. Frequency sweep rheology measurements were performed at $0.1 \%$ constant strain with logarithmic ramping from 0.1 to $100 \mathrm{rad} \mathrm{s}^{-1}$.

\subsection{Cell culture and maintenance}

Saos-2 cells (human osteosarcoma cell line, ATCCR HTB-85TM) were used in all cell culture experiments including viability, proliferation, ALP activity and calcium deposition. Cells were cultured in $75 \mathrm{~cm}^{2}$ flasks at $37{ }^{\circ} \mathrm{C}$ in a humidified incubator and supplied with 
$5 \% \mathrm{CO}_{2}$. Cells were maintained in Dulbecco's modified Eagle's medium (DMEM) supplemented with $10 \%$ fetal bovine serum (FBS), $1 \%$ penicillin/streptomycin and $2 \mathrm{mM} \mathrm{L-glutamine.} \mathrm{All} \mathrm{cell}$ experiments were carried out after reaching $90 \%$ confluency and subcultured at a ratio of $1: 6$ or $1: 8$. The culture medium was changed every 3-4 days. For mineralization experiments the seeded cell medium was replaced with osteogenic medium, DMEM with $10 \%$ FBS supplemented with $10 \mathrm{mM} \beta$-glycerophosphate, $50 \mu \mathrm{g} \mathrm{ml}^{-1}$ ascorbic acid and $10 \mathrm{nM}$ dexamethasone, after reaching confluency.

\subsection{Viability and proliferation}

The viability of Saos- 2 cells was studied at predetermined time intervals $(1,3$, and 5 days) by Calcein-AM staining. Briefly, cells were incubated on PA-coated and uncoated 24-well TCPs at a density of $5 \times 10^{3}$ cells $\mathrm{cm}^{-2}$. After 1,3 , and 5 days incubation the cell medium was discarded, the cells were washed with phosphate-buffered saline (PBS) and then incubated with $2 \mu \mathrm{M}$ Calcein-AM in PBS for 20-30 min at room temperature. Finally, 30 random images were taken at $10 \times$ magnification from each well for both qualitative and quantitative analysis by fluorescence microscopy. Cells were counted using the Image system for proliferation. Proliferation rates were determined by fitting the number of viable cells on day 1,3 , and 5 to exponential growth curves. All comparisons were made in accordance with the doubling time of cells on TCP.

\subsection{SEM imaging of Saos-2 cells on PA nanofiber-coated surfaces}

The morphology and spreading of Saos-2 cells were determined by SEM imaging using a FEI Quanta 200 FEG scanning electron microscope with an ETD detector in high vacuum mode and with a $10 \mathrm{keV}$ beam energy. For this purpose stainless steel surfaces were coated with $1 \mathrm{mM}$ PAs (ratios of $1: 3$ and $1: 2$ ) and then the cells were seeded on top of the coated and uncoated surfaces at a density of $2 \times 10^{4}$ cells per well. Stainless steel served as a conductive surface for SEM imaging. After 1 day incubation the cells were rinsed with PBS and fixed with $2 \%$ gluteraldehyde in PBS for $2 \mathrm{~h}$. Fixed cells were washed with PBS and then dehydrated sequentially in $20 \%, 40 \%, 60 \%, 80 \%$, and $100 \%$ ethanol. They were then critical point dried with an Autosamdri ${ }^{\circledR}-815 \mathrm{~B}$ Tousimis and coated with $5 \mathrm{~nm} \mathrm{Au} / \mathrm{Pd}$ before imaging. Energy dispersive X-ray analysis was performed at $80 \times$ magnification to determine the chemical composition of the samples.

\subsection{BMP-2 binding assay}

To analyze BMP-2 binding 1 and $0.1 \mathrm{mM}$ PA solutions were placed on ELISA plates at ratios of $1: 3$ and $1: 2$ for $\mathrm{SO}_{3}-\mathrm{PA} / \mathrm{K}-\mathrm{PA}$ and E-PA/K-PA, respectively. The plate was sealed and incubated at $4{ }^{\circ} \mathrm{C}$ overnight. Next day the wells were washed three times with washing buffer (Tween-20/PBS) and blocked with $300 \mu \mathrm{l}$ of $1 \%$ bovine serum albumin blocking solution for $2 \mathrm{~h}$. After blocking the wells were washed as above and then $100 \mu$ lof 100 or $10 \mathrm{ng} \mathrm{ml}^{-1}$ BMP-2 solution was added (PBS was used as a negative control) for $1 \mathrm{~h}$. Following BMP-2 incubation and washing $100 \mu \mathrm{l}$ of biotinylated anti-BMP-2 antibody at a $2 \mu \mathrm{g} \mathrm{ml}^{-1}$ was added to the wells and incubated for $1.5 \mathrm{~h}$ at $37^{\circ} \mathrm{C}$. After repeating the wash step $100 \mu \mathrm{l}$ of streptavidin coupled to horseradish peroxidase (1:200 dilutions) was added and incubated for $20 \mathrm{~min}$ in a dark room. The wells were then washed and $100 \mu \mathrm{l}$ of 3,3',5,5'-tetramethylbenzidine substrate was added to each. The plate was incubated at room temperature for $20 \mathrm{~min}$ in a dark room. Finally, $50 \mu \mathrm{l}$ of stop solution was added to each well and the optical density measured at $450 \mathrm{~nm}$ after $30 \mathrm{~min}$ incubation (readings were subtracted from the $540 \mathrm{~nm}$ absorbance). In order to determine percent binding of BMP-2 the wells were coated with $4 \mu \mathrm{g} \mathrm{ml}^{-1}$ anti-BMP-2 antibody instead of peptide nanofibers and incubated with 0,10 , 50 , and $100 \mathrm{ng} \mathrm{ml}^{-1}$ BMP-2. The percent binding of BMP-2 on nanofibers and bare TCP were calculated (Fig. S5) according to the formula obtained from the polynomial equation $y=$ $0.0001 x^{2}-0.0028 x+0.1441\left(R^{2}=0.9986\right)$.

\subsection{Alkaline phosphatase (ALP) activity assay}

The ALP activity of Saos- 2 cells was analyzed by measuring the colorimetric product of $p$-nitrophenol due to endogenous ALP activity after $1,3,7$, and 10 days culture in osteogenic medium in the presence and absence of BMP-2. Briefly, cells were seeded on PA nanofiber-coated and uncoated 48 -well TCP surfaces at a density of $3 \times 10^{4}$ cells per well. The next day the cell medium was replaced with osteogenic medium with or without BMP-2. At predetermined time points the cells were rinsed with PBS and protein extraction was performed using a M-PER protein extraction kit (Thermo) with $5 \%$ protease inhibitor solution at $150 \mu$ well $^{-1}$ for $30 \mathrm{~min}$ on a shaker. After centrifugation of the samples at $14,000 \mathrm{~g}$ for $10 \mathrm{~min}$ the supernatants containing protein were removed and a BCA protein assay performed to quantify the amount of protein obtained from the cells as described in the manufacturer's protocol. For ALP activity $50 \mu \mathrm{l}$ of the protein sample was incubated with $150 \mu$ l of $p$-nitrophenol phosphate substrate in 96-well plates for $30 \mathrm{~min}$ on a shaker. Serial dilutions of $p$-nitrophenol in $0.25 \mathrm{M} \mathrm{NaOH}$ solution were used as standards. Finally, the optical density was determined at $405 \mathrm{~nm}$ using a microplate reader. ALP results were normalized to the total amount of protein at a specific time point.

\subsection{Mineralization of Saos-2 cells by Alizarin red staining}

The ability for mineralized nodule formation and calcium deposition by Saos- 2 cells on PA nanofiber-coated and uncoated TCPs were assessed using Alizarin red-S staining as described previously [34]. In summary, cells were seeded on PA nanofiber-coated and uncoated 48 -well TCP surfaces at a density of $3 \times 10^{4}$ cells per well in growth medium. The next day the cell medium was replaced with osteogenic medium in the presence and absence of BMP-2 and the cells were incubated for 14 days. The cells were then washed with PBS and fixed in ice-cold ethanol for $1 \mathrm{~h}$ at room temperature. Afterwards the fixed cells were first washed with distilled water and then stained with $40 \mathrm{mM}$ Alizarin red-S solution ( $\mathrm{pH} 4.2$ ) for $30 \mathrm{~min}$ at room temperature on a shaker. After washing four or five times with distilled water to eliminate non-specific binding the calcium nodules were observed under a microscope.

\subsection{Statistical analysis}

All quantitative values are represented as means \pm SEM and all experiments were performed with at least three replicates for each group and for at least three independent repeats. Two-way analysis of variance (ANOVA) or Student's t-test were used for statistical analysis and a $P$ value of less than 0.05 was considered statistically significant.

\section{Results and discussion}

\subsection{Characterization of peptide amphiphile molecules and self- assembled nanofibers}

GAG mimetic and control peptide amphiphile molecules were designed and synthesized with or without sulfonate and carboxylate groups using solid phase peptide synthesis. $\mathrm{SO}_{3}-\mathrm{PA}$ was designed to mimic sulfonated GAGs by presenting functional 
groups such as sulfonate, hydroxyl and carboxylate groups (Fig. 1a). E-PA was designed to present carboxylate groups and had no sulfonate groups, mimicking non-sulfated GAGs (Fig. 1b).
Positively charged K-PA was synthesized in order to induce nanofiber formation together with negatively charged GAG mimetic peptide amphiphiles through electrostatic interactions (Fig. 1c).

(a)

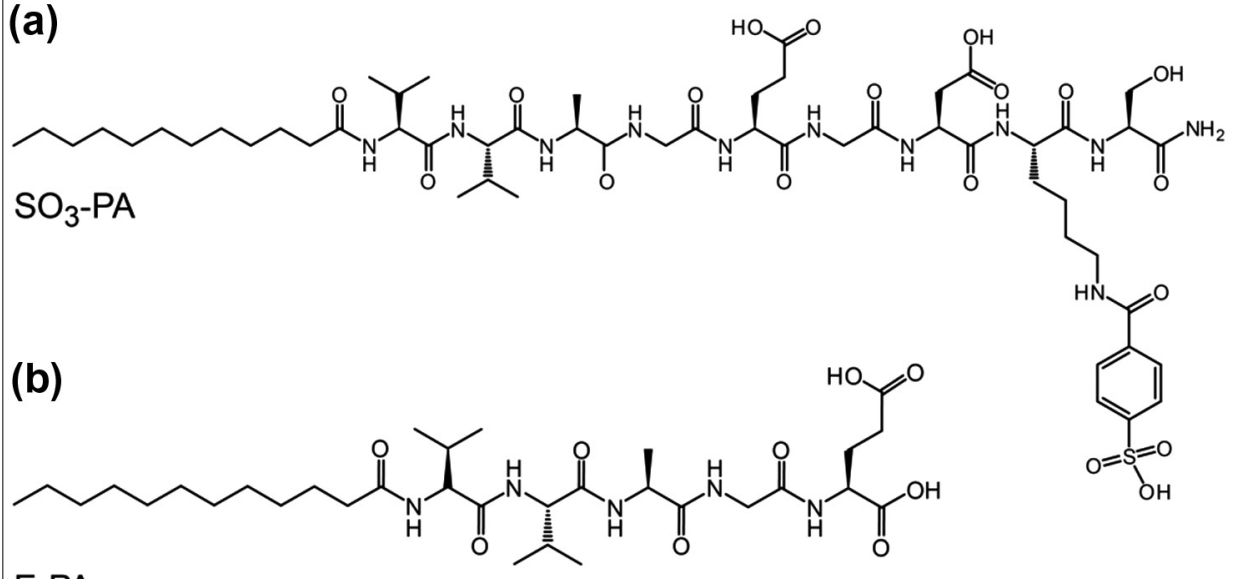
E-PA

(c)

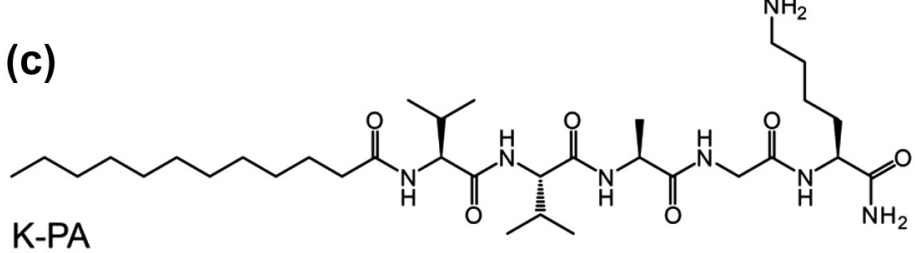
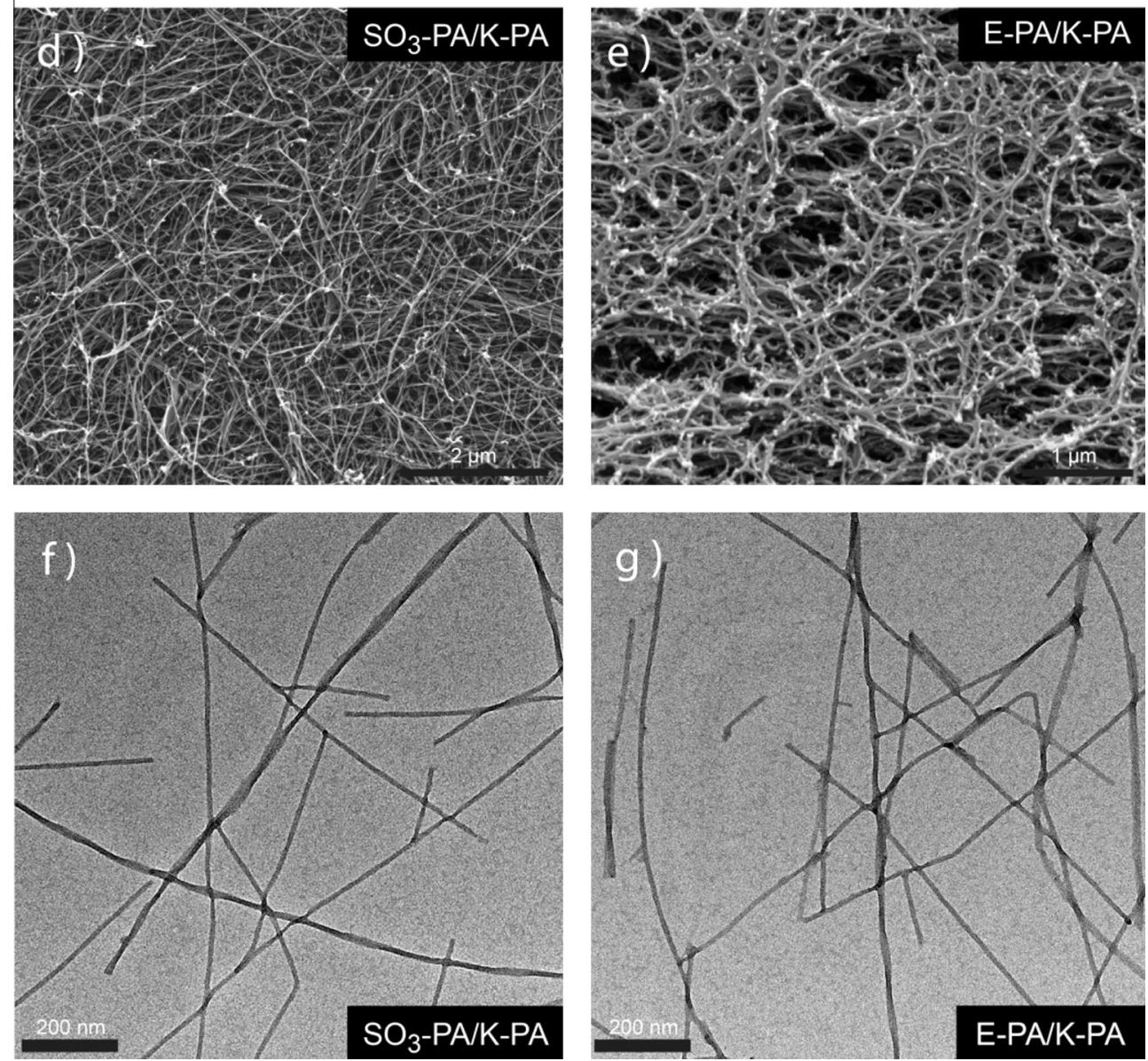

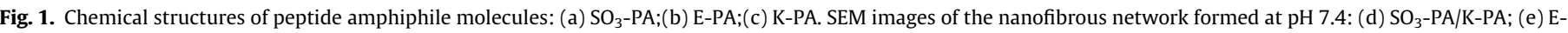
$\mathrm{PA} / \mathrm{K}-\mathrm{PA}$. TEM images of peptide nanofibers formed at $\mathrm{pH}$ 7.4: (f) $\mathrm{SO}_{3}-\mathrm{PA} / \mathrm{K}-\mathrm{PA}$; (g) E-PA/K-PA. 
$\mathrm{SO}_{3}$-PA and E-PA molecules form nanofibers through self-assembly when mixed with K-PA because of charge screening, hydrophobic collapse and $\beta$-sheet driving units in the VVAG peptide sequence at physiological $\mathrm{pH}$ [35]. The VVAG amino acid sequence was used as a common peptide motif in all peptide amphiphiles, because small side-chain residues with gradient hydrophilicity in this motif promote $\beta$-sheet-driven nanofiber elongation [3-5,31-33,36]. All of the peptide amphiphile molecules were characterized by liquid chromatography-mass spectrometry (LC-MS) and purified by preparative HPLC (Fig. S1). For charge neutralization $\mathrm{SO}_{3}-\mathrm{PA}$ and K-PA were mixed at a $1: 3$ ratio to form $\mathrm{SO}_{3}-\mathrm{PA} / \mathrm{K}-\mathrm{PA}$ nanofibers, whereas E-PA and K-PA were mixed at a 1:2 ratio to form E-PA/K-PA nanofibers. SEM images demonstrate the formation of a porous nanofiber network upon mixing oppositely charged PA molecules (Fig. 1d and e). The nanofiber network resembles native bone ECM, providing mechanical support and instructive cues for cells. Previous studies have elaborated the structural resemblance of peptide nanofibers to collagenous proteins found in bone ECM, such as collagen I, collagen III, and fibrillin, whose diameters vary from 10 to $100 \mathrm{~nm}$ [37-39]. TEM images revealed the formation of nanofibers with lengths ranging from a few hundred nanometers to at least 1-2 $\mu \mathrm{m}$ (Fig. $1 \mathrm{f}$ and g). Circular dichroism measurements revealed $\beta$-sheet formation with a chiral absorbance at $218 \mathrm{~nm}$ in both the $\mathrm{SO}_{3}-\mathrm{PA} / \mathrm{K}-\mathrm{PA}$ and $\mathrm{E}-\mathrm{PA} / \mathrm{K}-\mathrm{PA}$ mixtures (Fig. 2a). No $\beta$-sheet formation was observed when PAs were used alone (Fig. S2), which underlines the importance of charge neutralization for nanofiber formation. To further characterize self-assembly FTIR spectra of $\mathrm{SO}_{3}-\mathrm{PA} / \mathrm{K}-\mathrm{PA}$ and $\mathrm{E}-\mathrm{PA} / \mathrm{K}-\mathrm{PA}$ mixtures were analyzed. The most intense absorption band was found at around $1639 \mathrm{~cm}^{-1}$. Absorption at this wavenumber is referred to as the amide I peak, which had previously been reported to indicate $\beta$-sheet-rich secondary structure [40]. This observation is also consistent with $\beta$-sheet-driven self-assembled nanofiber formation by means of interactions between adjacent micelles, and with the results of circular dichroism measurements. The specific band at approximately $1043 \mathrm{~cm}^{-1}$ originating from S-O vibrations is a vibration signal of a sulfonate group in the $\mathrm{SO}_{3}-\mathrm{PA} / \mathrm{K}-\mathrm{PA}$ mixture. The rest of the characteristic peptide bands were similar for both PA mixtures, including amide II and COO- stretching bands (Fig. 2b). Frequency sweep rheology measurements at constant strain were performed in order to investigate gel formation and the viscoelastic properties of the gels,. The results revealed that gel formation occurred in both the $\mathrm{SO}_{3}-\mathrm{PA} / \mathrm{K}-\mathrm{PA}$ and E-PA/K-PA mixtures at $1 \mathrm{mM}$ concentration, since the storage modulus was higher than the loss modulus for all combinations (Fig. S3a and b). Frequency sweep measurements also revealed that both PA gels conserved their elastic behavior up to the range 50-60 $\mathrm{rads}^{-1}$.

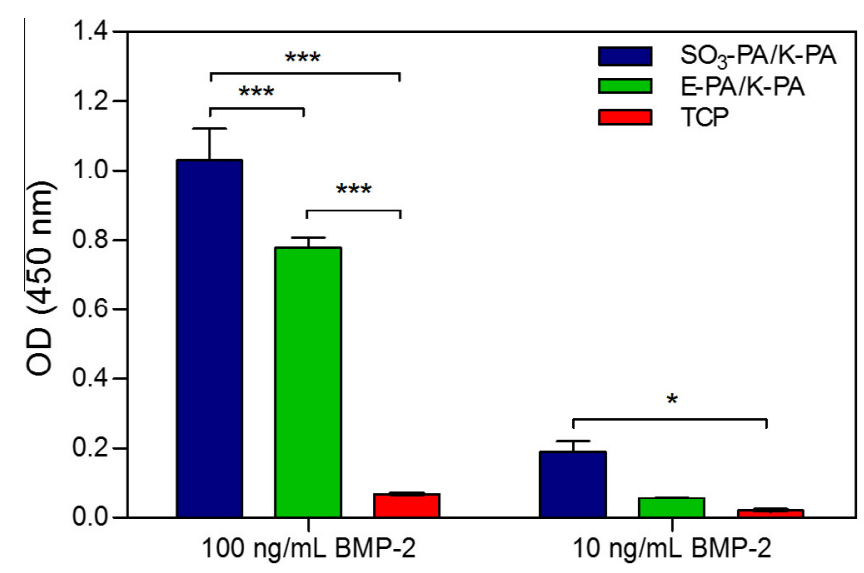

Fig. 3. Bmp-2 binding on GAG mimetic peptide nanofibers analyzed by ELISA assay. ${ }^{*} P<0.05 ;{ }^{* * *} P<0.001(n=3)$.

\subsection{BMP binding assay}

The bioactivity of GAGs mimicking peptide nanofiber systems on biomineralization was tested in terms of binding efficacy to BMP-2 through an ELISA based assay. For this purpose we immobilized peptide nanofibers on ELISA plates at 1 and $0.1 \mathrm{mM}$ concentrations and treated them with 100 or $10 \mathrm{ng} \mathrm{ml}^{-1}$ BMP- 2 for $2 \mathrm{~h}$. Our results showed that there was a 1.33-fold increase in binding of BMP-2 to $\mathrm{SO}_{3}-\mathrm{PA} / \mathrm{K}-\mathrm{PA}$ nanofibers compared with E-PA/K-PA nanofibers at $100 \mathrm{ng} \mathrm{ml}^{-1} \mathrm{BMP}-2(P<0.001)$ (Fig. 3). Polynomial calculations revealed that $88 \%$ of total BMP-2 bound to $\mathrm{SO}_{3}-\mathrm{PA} / \mathrm{K}-$ PA nanofibers, while $77 \%$ of total BMP-2 bound to E-PA/K-PA nanofibers. This difference indicated the effect of sulfonation on BMP-2 binding. In contrast, growth factor binding to bare ELISA plates was less than $10 \%$ at $100 \mathrm{ng} \mathrm{ml}^{-1}$ BMP-2. This shows that binding of BMP-2 to peptide nanofibers is specific at both BMP-2 concentrations $(P<0.001)$. When $10 \mathrm{ng} \mathrm{ml}^{-1} \mathrm{BMP}-2$ was used the binding patterns of BMP-2 on the $\mathrm{SO}_{3}-\mathrm{PA} / \mathrm{K}-\mathrm{PA}$ and E-PA/K-PA nanofibers were consistent with those treated with $100 \mathrm{ng} \mathrm{ml}^{-1}$ BMP-2. In addition, there was a 3.3-fold difference between BMP2 binding to $\mathrm{SO}_{3}-\mathrm{PA} / \mathrm{K}-\mathrm{PA}$ and E-PA/K-PA nanofibers at $10 \mathrm{ng} \mathrm{ml}^{-1}$ BMP-2. Similar binding patterns were observed for $\mathrm{SO}_{3}-\mathrm{PA} / \mathrm{K}-\mathrm{PA}$ and E-PA/K-PA nanofibers at $0.1 \mathrm{mM} \mathrm{PA}$ and $100 \mathrm{ng} \mathrm{ml}^{-1} \mathrm{BMP}-2$ (Fig. S4) ( $\mathrm{SO}_{3}-\mathrm{PA} / \mathrm{K}-\mathrm{PA}, 90 \%$; E-PA/K-PA, 77\%; bare surface $\left.<10 \%\right)$. The similar levels of BMP-2 binding at both BMP-2 concentrations showed saturation due to a high ligand density on the PA nanofibers.

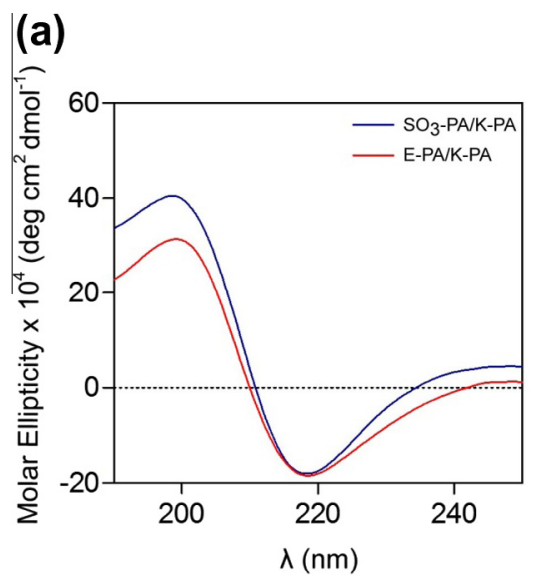

(b)

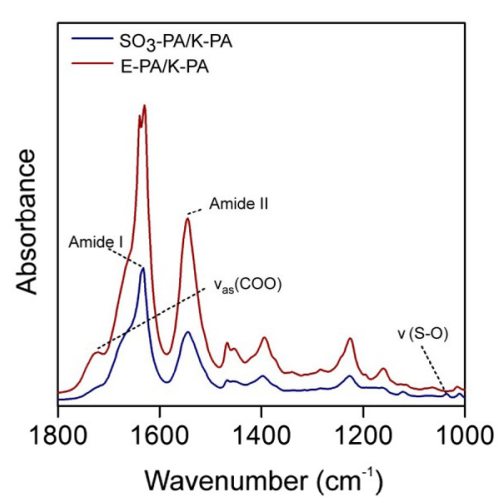

Fig. 2. (a) Circular dichroism and (b) FTIR spectra of $\mathrm{SO}_{3}-\mathrm{PA} / \mathrm{K}-\mathrm{PA}$ and E-PA/K-PA peptide nanofibers. 

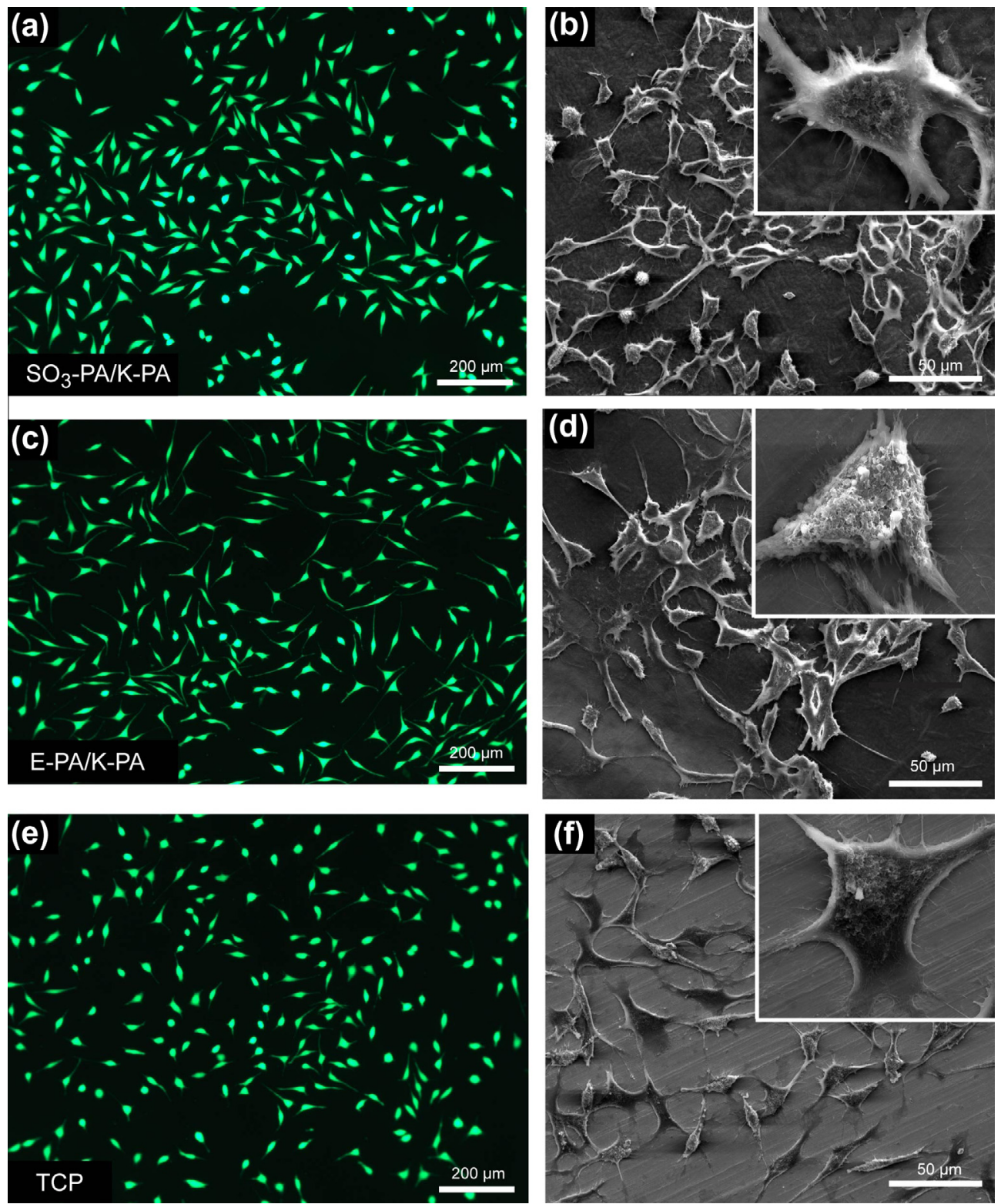

Fig. 4. Viability and morphology of Saos-2 cells on GAG mimetic peptide nanofibers after 3 days incubation. (a and b) SO $\mathrm{S}_{3}-\mathrm{PA} / \mathrm{K}-\mathrm{PA}$; (c and d) E-PA/K-PA; (e and f) TCP ( $n=4$ ).

\subsection{Cellular behavior on PA nanofibers}

In order to test the effect of GAGs mimetic peptide nanofibers on cell viability and proliferation we cultured osteoblast-like Saos- 2 cells on peptide nanofibers over a 5 day period. Saos- 2 cells were viable on all surfaces after 3 days incubation (Fig. 4). SEM images revealed that Saos- 2 cells had spread and attained their characteristic morphology on all of the surfaces by day 3 (Fig. S7). These results indicated that peptide nanofibers provide a biocompatible microenvironment for Saos-2 cells. The number of live cells on all samples was similar after 1 day incubation, which indicates that equal numbers of cells adhered to all surfaces and remained viable after $24 \mathrm{~h}$. At the end of day 3 the number of live cells increased 4-fold with respect to the cell numbers on day 1, which shows that the cells had proliferated (Fig. 5). The peptide nanofiber network was stable in the presence of serum proteins and cellular activity, which is desired for sustainable induction of osteogenesis for an at least initial period of time (Fig. S6). These results imply that GAGs mimetic peptide nanofibers provide a favorable environment for cell viability and proliferation.

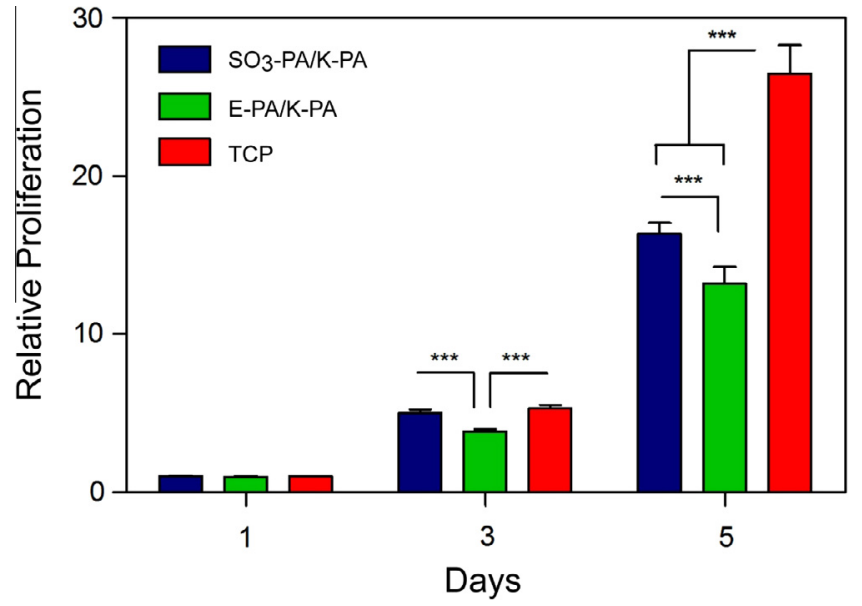

Fig. 5. Proliferation of Saos-2 cells on GAG mimetic peptide nanofibers over the course of 5 days. ${ }^{* * *} P<0.001(n=4)$. 


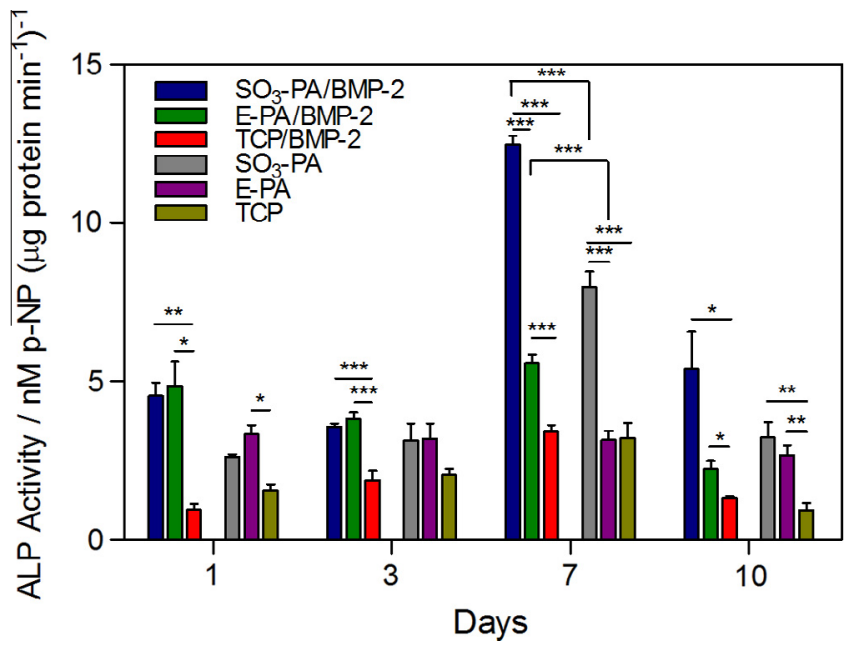

Fig. 6. Impact of GAG mimetic peptide nanofibers on alkaline phosphatase activity of Saos-2 cells in the presence $\left(100 \mathrm{ng} \mathrm{ml}^{-1}\right)$ or absence of BMP-2. ${ }^{*} P<0.05$; ${ }^{* *} P<0.01$; ${ }^{* * *} P<0.001(n=4)$.
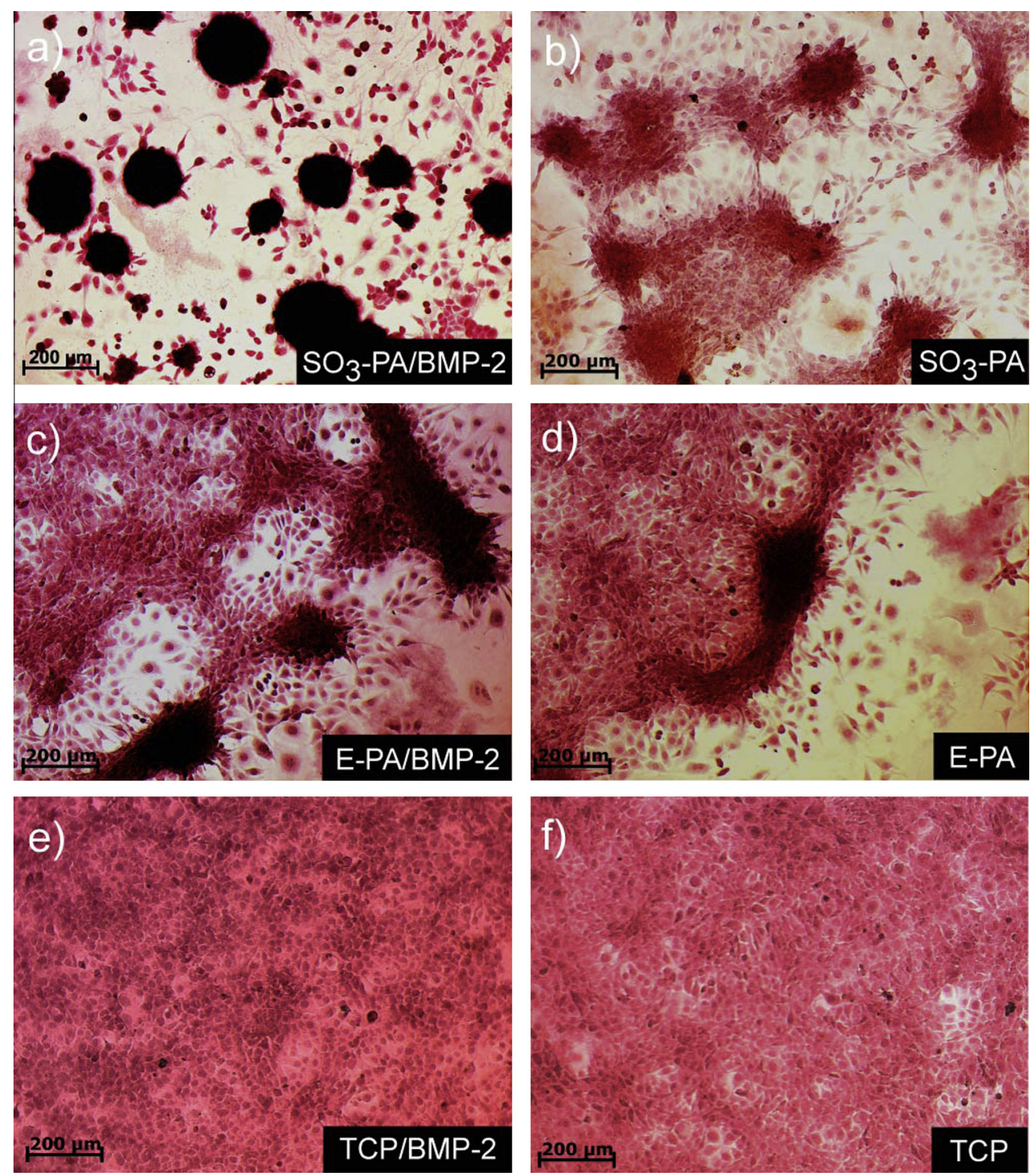

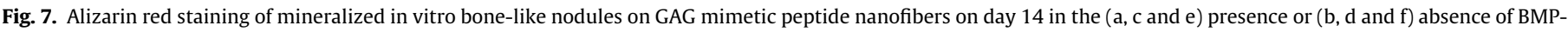
2. (a and b) $\mathrm{SO}_{3}-\mathrm{PA} / \mathrm{K}-\mathrm{PA}$; (c and d) E-PA/K-PA; (e, f) bare surface. 

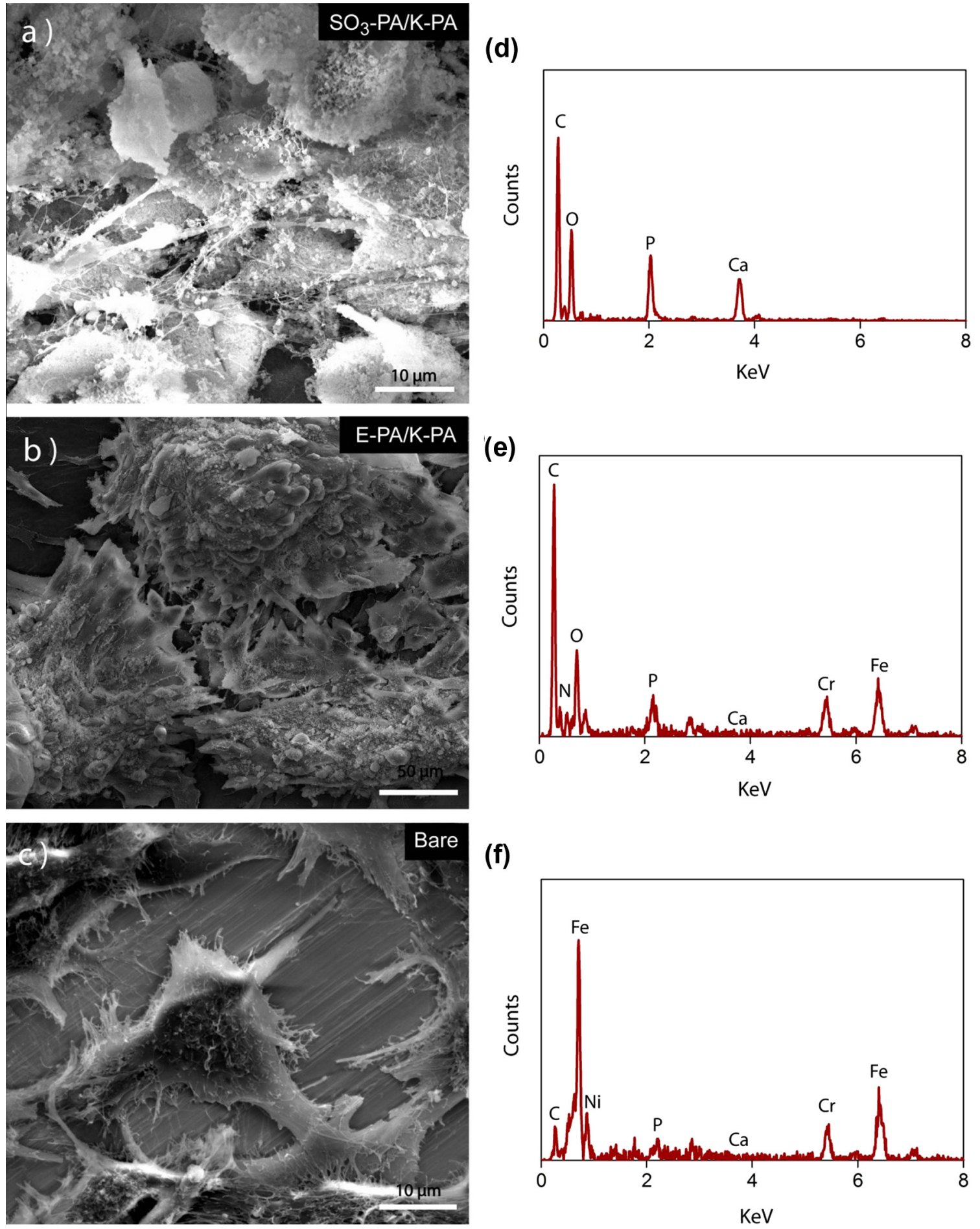

(f)

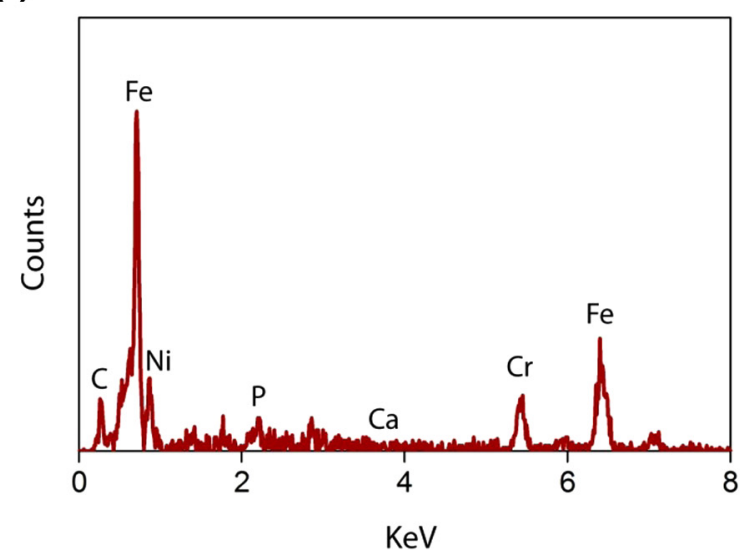

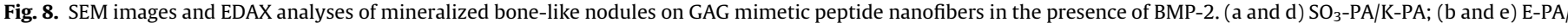
$\mathrm{K}-\mathrm{PA}$; (c and f) bare surface.

medium. Maximum ALP activity was observed on day 7 for all samples, thereafter decreasing to day 10 (Fig. 6). On day 1 cells cultured on $\mathrm{SO}_{3}-\mathrm{PA} / \mathrm{K}-\mathrm{PA}$ and E-PA/K-PA showed higher ALP activity compared with those cultures on TCP $\left(P<0.01\right.$ for $\mathrm{SO}_{3}-\mathrm{PA} / \mathrm{K}-\mathrm{PA}$, $P<0.05$ for E-PA/K-PA). BMP-2 increased the ALP activity almost 2 -fold on $\mathrm{SO}_{3}-\mathrm{PA} / \mathrm{K}-\mathrm{PA}$ nanofibers and 1.5 -fold on E-PA/K-PA nanofibers, while it did not change ALP activity on TCP. On day 3 ALP activity of cells were still significantly higher on PA-coated surfaces compared with TCP, however, BMP-2 treatment did not affect ALP activity $(P<0.001)$. The presence of BMP-2 did not alter the ALP activity of Saos-2 cells on TCP over 10 days incubation under these conditions. Since GAGs stabilize growth factors and increase their localization, growth factors could be more rapidly degraded in the serum environment and internalized via cell surface heparan sulfates in the absence of matrix GAGs [44]. Thus, in the absence of extracellular GAGs a higher exogenous BMP-2 concentration might be required to induce receptor activation and osteogenic activity. To test this hypothesis Saos-2 cells were 
Table 1

Elemental analysis of mineralized bone-like nodules by EDAX spectroscopy.

\begin{tabular}{|c|c|c|c|c|c|c|c|c|c|}
\hline \multirow[t]{2}{*}{ Sample } & \multicolumn{8}{|c|}{ Elemental composition (\%) } & \multirow[t]{2}{*}{$\mathrm{Ca} / \mathrm{P}$ ratio } \\
\hline & $\mathrm{C}$ & $\mathrm{N}$ & 0 & $\mathrm{Ni}$ & $\mathrm{P}$ & $\mathrm{Ca}$ & $\mathrm{Cr}$ & $\mathrm{Fe}$ & \\
\hline $\mathrm{SO}_{3}-\mathrm{PA} / \mathrm{K}-\mathrm{PA}$ & 53.34 & 11.44 & 24.55 & & 3.87 & 4.98 & & 1.82 & 1.29 \\
\hline E-PA/K-PA & 58.97 & 7.56 & 2.17 & 2.9 & 0.42 & 0.2 & 6.72 & 21.07 & 0.48 \\
\hline Bare & 16.31 & 2.78 & & 12.32 & 0.29 & 0.3 & 14.52 & 53.48 & 1.03 \\
\hline
\end{tabular}

The Ni, Cr, and Fe signals correspond to the stainless steel substrate, which is a conductive platform enabling SEM imaging and EDAX analysis.

treated with up to $400 \mathrm{ng} \mathrm{ml}^{-1}$ BMP-2, however, the ALP activity of Saos- 2 cells increased slightly, from 3.34 to 5.29 fold upon BMP-2 addition after 4 days incubation (Fig. S8). A similar change in the osteogenic activity of Saos-2 cells was previously shown on increasing the BMP-2 concentration to $500 \mathrm{ng} \mathrm{ml}^{-1}$ [45].

Maximum ALP activity was observed on day 7 for all samples and the highest ALP production was seen on $\mathrm{SO}_{3}-\mathrm{PA} / \mathrm{K}-\mathrm{PA}$ nanofibers in the presence of BMP-2. On day 7 culture on $\mathrm{SO}_{3}-\mathrm{PA} / \mathrm{K}-\mathrm{PA}$ nanofibers enhanced the ALP activity in Saos-2 cells with respect to both E-PA/K-PA nanofibers $(P<0.001)$ and TCP $(P<0.001)$, even in the absence of BMP-2 treatment. In the absence of BMP-2 the ALP activity of Saos-2 cells on $\mathrm{SO}_{3}-\mathrm{PA} / \mathrm{K}-\mathrm{PA}$ nanofibers was significantly higher ( 2.5-fold) than those on both E-PA/KPA and TCP. This increase in the ALP activity without BMP-2 treatment could be due to the endogenous expression of growth factors and their autocrine signaling through interaction with peptide nanofibers and an increase of their local concentrations. Moreover, the direct interaction of chemical groups found on peptide nanofibers, such as carboxylate groups, with cell surface molecules, as in the CD44-hyaluronan interaction, could be responsible for the increase in ALP expression [16,46]. BMP-2 treatment also increased the ALP activity of Saos- 2 cells on both $\mathrm{SO}_{3}-\mathrm{PA} / \mathrm{K}-\mathrm{PA}$ and E-PA/K-PA nanofibers, whereas no such difference was observed on TCP $(P<0.001)$. In the presence of BMP-2 the ALP activity of Saos-2 cells on $\mathrm{SO}_{3}-\mathrm{PA} / \mathrm{K}-\mathrm{PA}$ nanofibers was also higher than those on E-PA/K-PA ( $\sim 2.2$-fold $)$ and TCP ( $\sim 3.4$-fold). On day 10 the ALP activity of the cells decreased for all samples, but the significant difference between peptide nanofiber-coated samples and TCP continued both in the presence and absence of BMP-2. Since ALP expression is an early marker of mineralization, the decrease in ALP activity after day 7 can be explained by the commencement of matrix mineralization, adequate amounts of inorganic phosphate having been produced [47]. Moreover, only cells cultured on $\mathrm{SO}_{3}-\mathrm{PA} / \mathrm{K}-\mathrm{PA}$ nanofibers showed higher ALP activity in the presence of BMP-2 compared with samples without BMP-2 treatment. Overall, the ALP activity of Saos-2 cells always remained higher on GAG mimetic PA nanofibers compared with TCP over 10 days incubation. The presence of BMP-2 increased ALP activity, particularly on sulfonated peptide nanofibers, on nearly all days tested and slightly increased that of E-PA/K-PA on day 7, whereas no significant difference was observed for TCP samples in the presence of BMP-2 on any of the days. This result might have been caused by enhanced cellular responses to BMP-2 in the presence of GAG mimetic peptide nanofibers, since heparansulfate GAGs were previously shown to alter BMP-2 responses [44]. The difference between the ALP activity of cells on $\mathrm{SO}_{3}-\mathrm{PA} / \mathrm{K}-\mathrm{PA}$ and E-PA/K-PA nanofibers could be due to the different binding abilities to BMP-2 of these nanofibers, as shown in Fig. 3. Since $\mathrm{SO}_{3}-\mathrm{PA} / \mathrm{K}-\mathrm{PA}$ nanofibers can bind to BMP-2 better than E-PA/K-PA nanofibers they could enhance BMP-2 activity by increasing the local concentration of BMP-2, which is endogenously secreted by osteoblasts. Similarly to this effect, modification of hyaluronan with sulfate groups was previously shown to increase the binding affinity for bone morphogenetic proteins [48].

\subsection{Mineralization on bioactive peptide nanofibers}

To determine the mineral deposition ability of osteoblast-like cells we performed Alizarin red-S staining in the presence and absence of BMP-2. Alizarin red-S staining, which chelates $\mathrm{Ca}^{2+}$, is a commonly used method to evaluate mineralization [49]. The migration and aggregate formation of osteoblasts prior to mineralized nodule formation has previously been shown [50-52]. Saos-2 cells formed mineralized bone-like nodules upon migration on the $\mathrm{SO}_{3}-\mathrm{PA} / \mathrm{K}-\mathrm{PA}$ and E-PA/K-PA nanofibers after 14 days incubation, both in the presence and absence of BMP-2 (Fig. 7). Compared with cells cultured on E-PA/K-PA nanofibers, more mineralized nodules formed on $\mathrm{SO}_{3}-\mathrm{PA} / \mathrm{K}-\mathrm{PA}$ nanofibers and the nodules on $\mathrm{SO}_{3}-\mathrm{PA} / \mathrm{K}-$ $\mathrm{PA}$ were larger and denser in the presence of BMP-2. Mineralized nodule formation was also observed on E-PA/K-PA surfaces, both in the presence and absence of BMP-2. However, no mineralized nodule formation was observed on TCP even at the end of 14 days.

To further investigate the chemical composition of mineralized nodules SEM and EDAX analyses were performed after 14 days incubation on coated and uncoated stainless steel surfaces in the presence of BMP-2. SEM images revealed the presence of calcium and phosphate in nodules of cells cultured on both $\mathrm{SO}_{3}-\mathrm{PA} / \mathrm{K}-\mathrm{PA}$ and E-PA/K-PA nanofibers (Fig. 8a and b). Similar to the results on TCP, no nodule formation was observed on uncoated stainless steel surfaces (Fig. 8c). EDAX spectra obtained from these samples revealed specific $\mathrm{C}, \mathrm{N}$ and $\mathrm{O}$ peaks on both $\mathrm{SO}_{3}-\mathrm{PA} / \mathrm{K}-\mathrm{PA}$ and $\mathrm{E}-\mathrm{PA} /$ $\mathrm{K}-\mathrm{PA}$ nanofibers, indicating the presence of the peptide nanofiber at the end of day 14 (Fig. 8d and e). However, Ca and $\mathrm{P}$ peaks were predominantly observed on $\mathrm{SO}_{3}-\mathrm{PA} / \mathrm{K}-\mathrm{PA}$ nanofibers. $\mathrm{Ca}$ and $\mathrm{P}$ were also present on E-PA/K-PA nanofibers, but their abundance was dramatically lower than on $\mathrm{SO}_{3}-\mathrm{PA} / \mathrm{K}-\mathrm{PA}$ nanofibers. The $\mathrm{Ca} /$ $\mathrm{P}$ ratios of bone nodules formed on these peptide nanofibers were 1.29 and 0.48 for $\mathrm{SO}_{3}-\mathrm{PA} / \mathrm{K}-\mathrm{PA}$ and $\mathrm{E}-\mathrm{PA} / \mathrm{K}-\mathrm{PA}$, respectively (Table 1). Uncoated stainless steel surfaces showed Fe and Ni peaks (as the surface was not coated with nanofibers), while Ca and P peaks were still detectable on these surfaces. The $\mathrm{Ca} / \mathrm{P}$ ratio of the bare surface was 1.03 . Regarding the stoichiometric $\mathrm{Ca} / \mathrm{P}$ ratios we obtained, we deduced that deposited minerals in bone-like nodules could be in the form of tricalcium phosphate and $\mathrm{Ca}_{2} \mathrm{P}_{2} \mathrm{O}_{7}$. These phases were previously observed at $\mathrm{Ca} / \mathrm{P}$ ratios less than 1.33 [53-54]. It is noteworthy that cells cultured on sulfonated peptide nanofibers exhibited significantly more mineral deposition compared with cells cultured on peptide nanofibers without sulfonyl groups, although the two peptide nanofibers showed similar initial responses, and no mineralized nodule formation was observed on uncoated surfaces.

\section{Conclusions}

In summary, we have demonstrated that a GAG mimetic peptide nanofiber system could bind BMP-2 and provided a biocompatible environment to promote osteoblastic cell viability, spreading and proliferation. These nanofibers demonstrated osteoinductive properties. Osteoblast cells cultured on these peptide 
nanofibers exhibited enhanced alkaline phosphatase activity and calcium deposition, which are the main indicators of bone-like mineralization. In addition, osteogenic activity of osteoblast-like cells in the presence of BMP-2 was boosted by sulfonated peptide nanofibers. As a clinical extension GAG mimetic peptide nanofiber structures possess the potential to be utilized in bone regeneration applications, either being used directly or serving as a carrier when used together with an inductive growth factor.

\section{Acknowledgements}

We would like to express our gratitude to Z. Erdogan for her help with LC-MS and M. Guler for his help with TEM. This work was financially supported by the Scientific and Technological Research Council of Turkey (TUBITAK) by Grants 112 T042 and 110M355, and a COMSTECH-TWAS grant. S.K. and H.C. are supported by TUBITAK BIDEB fellowships. M.O.G. and A.B.T. acknowledge support from the Turkish Academy of Sciences Distinguished Young Scientist Award (TUBA GEBIP).

\section{Appendix A. Supplementary data}

Supplementary data associated with this article can be found, in the online version, at http://dx.doi.org/10.1016/j.actbio.2013.07. 007.

\section{Appendix B. Figures with essential color discrimination}

Certain figures in this article, particularly Graphical abstract and Figs. 2-8, are difficult to interpret in black and white. The full color images can be found in the on-line version, at http://dx.doi.org/ 10.1016/j.actbio.2013.07.007.

\section{References}

[1] Carson JS, Bostrom MP. Synthetic bone scaffolds and fracture repair. Injury 2007;38(Suppl. 1):S33-7.

[2] Hartgerink JD, Beniash E, Stupp SI. Peptide-amphiphile nanofibers: a versatile scaffold for the preparation of self-assembling materials. Proc Natl Acad Sci USA 2002;99:5133-8

[3] Ceylan H, Tekinay AB, Guler MO. Selective adhesion and growth of vascular endothelial cells on bioactive peptide nanofiber functionalized stainless steel surface. Biomaterials 2011;32:8797-805.

[4] Ceylan H, Kocabey S, Tekinay AB, Guler MO. Surface-adhesive and osteogenic self-assembled peptide nanofibers for bioinspired functionalization of titanium surfaces. Soft Matter 2012;8:3929-37.

[5] Ustun S, Tombuloglu A, Kilinc M, Guler MO, Tekinay AB. Growth and differentiation of prechondrogenic cells on bioactive self-assembled peptide nanofibers. Biomacromolecules 2013;14:17-26.

[6] Pham QP, Kasper FK, Scott Baggett L, Raphael RM, Jansen JA, Mikos AG. The influence of an in vitro generated bone-like extracellular matrix on osteoblastic gene expression of marrow stromal cells. Biomaterials 2008;29:2729-39.

[7] Bi Y, Stuelten CH, Kilts T, Wadhwa S, Iozzo RV, Robey PG, et al. Extracellular matrix proteoglycans control the fate of bone marrow stromal cells. J Biol Chem 2005;280:30481-9.

[8] Rozario T, DeSimone DW. The extracellular matrix in development and morphogenesis: a dynamic view. Dev Biol 2010;341:126-40.

[9] Robey PG, Boskey AL, ASBMR. The composition of bone. In: Primer on the metabolic bone diseases and disorders of mineral metabolism. New York: John Wiley; 2009. p. 32-8 [chapter 6].

[10] Taipale J, Keski-Oja J. Growth factors in the extracellular matrix. FASEB J 1997;11:51-9.

[11] Mania VM, Kallivokas AG, Malavaki C, Asimakopoulou AP, Kanakis J, Theocharis AD, et al. A comparative biochemical analysis of glycosaminoglycans and proteoglycans in human orthotopic and heterotopic bone. IUBMB Life 2009;61:447-52.

[12] van der Harst MR, Brama PA, van de Lest CH, Kiers GH, DeGroot J, van Weeren PR. An integral biochemical analysis of the main constituents of articular cartilage, subchondral and trabecular bone. Osteoarthritis Cartilage 2004;12:752-61.

[13] Prince CW, Navia JM. Glycosaminoglycan alterations in rat bone due to growth and fluorosis. J Nutr 1983;113:1576-82.
[14] Benoit DS, Anseth KS. Heparin functionalized PEG gels that modulate protein adsorption for hMSC adhesion and differentiation. Acta Biomater 2005; 1:461-70.

[15] Mathews S, Mathew SA, Gupta PK, Bhonde R, Totey S. Glycosaminoglycans enhance osteoblast differentiation of bone marrow derived human mesenchymal stem cells. J Tissue Eng Regener Med 2013. http://dx.doi.org/ 10.1002/term.1507.

[16] Peach RJ, Hollenbaugh D, Stamenkovic I, Aruffo A. Identification of hyaluronic acid binding sites in the extracellular domain of CD44. J Cell Biol 1993;122:257-64.

[17] Comper WD. Extracellular Matrix. Newark, NJ: Harwood Acad; 1996.

[18] Solis MA, Chen YH, Wong TY, Bittencourt VZ, Lin YC, Huang LL. Hyaluronan regulates cell behavior: a potential niche matrix for stem cells. Biochem Res Int 2012;2012:346972.

[19] Miyazaki T, Miyauchi S, Tawada A, Anada T, Matsuzaka S, Suzuki O. Oversulfated chondroitin sulfate-E binds to BMP-4 and enhances osteoblast differentiation. J Cell Physiol 2008;217:769-77.

[20] Nagahata M, Tsuchiya T, Ishiguro T, Matsuda N, Nakatsuchi Y, Teramoto A et al. A novel function of $\mathrm{N}$-cadherin and Connexin43: marked enhancement of alkaline phosphatase activity in rat calvarial osteoblast exposed to sulfated hyaluronan. Biochem Biophys Res Commun 2004;315:603-11.

[21] Theoleyre S, Kwan Tat S, Vusio P, Blanchard F, Gallagher J, Ricard-Blum S, et al Characterization of osteoprotegerin binding to glycosaminoglycans by surface plasmon resonance: role in the interactions with receptor activator of nuclear factor kappaB ligand (RANKL) and RANK. Biochem Biophys Res Commun 2006;347:460-7.

[22] Lamoureux F, Picarda G, Garrigue-Antar L, Baud'huin M, Trichet V, Vidal A, et al. Glycosaminoglycans as potential regulators of osteoprotegerin therapeutic activity in osteosarcoma. Cancer Res 2009;69:526-36.

[23] Rider CC. Heparin/heparan sulphate binding in the TGF-beta cytokine superfamily. Biochem Soc Trans 2006;34:458-60.

[24] Shinmyouzu K, Takahashi T, Ariyoshi W, Ichimiya H, Kanzaki S, Nishihara T. Dermatan sulfate inhibits osteoclast formation by binding to receptor activator of NF-kappa B ligand. Biochem Biophys Res Commun 2007;354:447-52.

[25] Fromigue O, Marie PJ, Lomri A. Bone morphogenetic protein-2 and transforming growth factor-beta2 interact to modulate human bone marrow stromal cell proliferation and differentiation. J Cell Biochem 1998;68:411-26.

[26] Lecanda F, Avioli LV, Cheng SL. Regulation of bone matrix protein expression and induction of differentiation of human osteoblasts and human bone marrow stromal cells by bone morphogenetic protein-2. J Cell Biochem 1997;67:386-96.

[27] Groeneveld EH, Burger EH. Bone morphogenetic proteins in human bone regeneration. Eur J Endocrinol 2000;142:9-21.

[28] Hollinger JO, Schmitt JM, Buck DC, Shannon R, Joh SP, Zegzula HD, et al. Recombinant human bone morphogenetic protein-2 and collagen for bone regeneration. J Biomed Mater Res 1998;43:356-64.

[29] Ruppert R, Hoffmann E, Sebald W. Human bone morphogenetic protein 2 contains a heparin-binding site which modifies its biological activity. Eur J Biochem 1996;237:295-302.

[30] Hynes RO. The extracellular matrix: not just pretty fibrils. Science 2009;326:1216-9.

[31] Mammadov R, Mammadov B, Guler MO, Tekinay AB. Growth factor binding on heparin mimetic peptide nanofibers. Biomacromolecules 2012;13:3311-9.

[32] Mammadov R, Mammadov B, Toksoz S, Aydin B, Yagci R, Tekinay AB, et al. Heparin mimetic peptide nanofibers promote angiogenesis. Biomacromolecules 2011;12:3508-19.

[33] Mammadov B, Mammadov R, Guler MO, Tekinay AB. Cooperative effect of heparan sulfate and laminin mimetic peptide nanofibers on the promotion of neurite outgrowth. Acta Biomater 2012;8:2077-86.

[34] Stanford CM, Jacobson PA, Eanes ED, Lembke LA, Midura RJ. Rapidly forming apatitic mineral in an osteoblastic cell line (UMR 106-01 BSP). J Biol Chem 1995;270:9420-8.

[35] Niece KL, Hartgerink JD, Donners JJ, Stupp SI. Self-assembly combining two bioactive peptide-amphiphile molecules into nanofibers by electrostatic attraction. J Am Chem Soc 2003;125:7146-7.

[36] Smith CK, Withka JM, Regan L. A thermodynamic scale for the beta-sheet forming tendencies of the amino acids. Biochemistry 1994;33:5510-7.

[37] Keene DR, Sakai LY, Burgeson RE. Human bone contains type III collagen, type VI collagen, and fibrillin: type III collagen is present on specific fibers that may mediate attachment of tendons, ligaments, and periosteum to calcified bone cortex. J Histochem Cytochem 1991;39:59-69.

[38] Matthews JA, Wnek GE, Simpson DG, Bowlin GL. Electrospinning of collagen nanofibers. Biomacromolecules 2002;3:232-8.

[39] Taton TA. Nanotechnology. Boning up on biology. Nature 2001;412:491-2.

[40] Halverson KJ, Sucholeiki I, Ashburn TT, Lansbury PT. Location of beta-sheetforming sequences in amyloid proteins by FTIR. J Am Chem Soc 1991;113:6701-3.

[41] Dombrowski C, Song SJ, Chuan P, Lim X, Susanto E, Sawyer AA, et al. Heparan sulfate mediates the proliferation and differentiation of rat mesenchymal stem cells. Stem Cells Dev 2009;18:661-70.

[42] Nikitovic D, Zafiropoulos A, Tzanakakis GN, Karamanos NK, Tsatsakis AM. Effects of glycosaminoglycans on cell proliferation of normal osteoblasts and human osteosarcoma cells depend on their type and fine chemical compositions. Anticancer Res 2005;25:2851-6.

[43] Addison WN, Azari F, Sorensen ES, Kaartinen MT, McKee MD. Pyrophosphate inhibits mineralization of osteoblast cultures by binding to mineral, up- 
regulating osteopontin, and inhibiting alkaline phosphatase activity. J Biol Chem 2007;282:15872-83.

[44] Jiao X, Billings PC, O'Connell MP, Kaplan FS, Shore EM, Glaser DL. Heparan sulfate proteoglycans (HSPGs) modulate BMP2 osteogenic bioactivity in C2C12 cells. J Biol Chem 2007;282:1080-6.

[45] Turhani D, Weissenbock M, Stein E, Wanschitz F, Ewers R. Exogenous recombinant human BMP-2 has little initial effects on human osteoblastic cells cultured on collagen type I coated/noncoated hydroxyapatite ceramic granules. J Oral Maxillofac Surg 2007;65:485-93.

[46] Rawadi G, Vayssiere B, Dunn F, Baron R, Roman-Roman S. BMP-2 controls alkaline phosphatase expression and osteoblast mineralization by a Wnt autocrine loop. J Bone Miner Res 2003;18:1842-53.

[47] Storrie H, Stupp SI. Cellular response to zinc-containing organoapatite: an in vitro study of proliferation, alkaline phosphatase activity and biomineralization. Biomaterials 2005;26:5492-9.

[48] Hintze V, Moeller S, Schnabelrauch M, Bierbaum S, Viola M, Worch H, et al. Modifications of hyaluronan influence the interaction with human bone morphogenetic protein-4 (hBMP-4). Biomacromolecules 2009;10:3290-7.
[49] McGee-Russell SM. Histochemical methods for calcium. J Histochem Cytochem 1958;6:22-42.

[50] Fedde KN. Human osteosarcoma cells spontaneously release matrix-vesiclelike structures with the capacity to mineralize. Bone Miner 1992;17:145-51.

[51] Buttery LD, Bourne S, Xynos JD, Wood $H$, Hughes FJ, Hughes SP, et al. Differentiation of osteoblasts and in vitro bone formation from murine embryonic stem cells. Tissue Eng 2001;7:89-99.

[52] Nefussi JR, Brami G, Modrowski D, Oboeuf M, Forest N. Sequential expression of bone matrix proteins during rat calvaria osteoblast differentiation and bone nodule formation in vitro. J Histochem Cytochem 1997;45:493-503.

[53] Liu H, Yazici H, Ergun C, Webster T, Bermek H. An in vitro evaluation of the Ca/ $\mathrm{P}$ ratio for the cytocompatibility of nano-to-micron particulate calcium phosphates for bone regeneration. Acta Biomater 2008;4:1472-9.

[54] Ergun C, Liu H, Webster T, Olcay E, Yilmaz S, Sahin F. Increased osteoblast adhesion on nanoparticulate calcium phosphates with higher $\mathrm{Ca} / \mathrm{P}$ ratios. Biomed Mater Res A 2008;85:236-41. 